\title{
Willingness to commute among future physicians: a multicenter cross-sectional survey of German medical students
}

\author{
Johannes Quart ${ }^{1,2+}$, Tobias Deutsch ${ }^{1 * \dagger}$, Solveig Carmienke ${ }^{2}$, Susanne Döpfmer ${ }^{3}$ and Thomas Frese $^{2}$
}

\begin{abstract}
Background: Many countries are faced with a decrease in physicians in non-urban areas. Especially for regions with decreasing populations, temporary solutions like commuting models might be a suitable option. So far, little is known about the willingness to commute among future physicians.

Methods: In this multicenter, cross-sectional survey, five years of medical students (8th to 10th semester) from three German universities (Charité Berlin, Halle, Leipzig) were questioned about their willingness to commute to work, the maximum acceptable commute time, and how several job-related factors might enhance the attractiveness of commuting.

Results: Altogether 1108 of 1203 (92.1\%) students completed the questionnaire. For 55.9\% of the participants it was imaginable to commute to a non-urban area in the future. The most important job-related factors that would increase the attractiveness of such a commuting model were remuneration of the commuting time, higher remuneration in general, working self-employed in a joint practice with 2-3 physicians, existence of a specifically qualified "supply assistant", provision of a home office, good public transport connection, and a driver service. The maximum acceptable commute time was on average 39.0 min (one-way). If the way to work would be a salaried integral part of the normal working time, the participants stated they would accept traveling 51.2 min (one-way).

Conclusions: Most future physicians are open-minded regarding models of commuting. The attractiveness of such models can be increased mainly through higher remuneration, reduction of the physicians' burden, and comfortable modes of transport.
\end{abstract}

Keywords: Physician shortage, Commuting, Non-urban areas, Primary care, General practice

\section{Abstract German}

Hintergrund: Viele Länder stehen vor der Herausforderung eines zunehmenden Ärztemangels in ländlichen Regionen. Insbesondere für Gebiete mit rückläufigen Bevölkerungszahlen könnten Pendelmodelle eine praktikable temporäre Lösung darstellen. Über die Pendelbereitschaft zukünftiger Ärzte ist bisher wenig bekannt.

(Continued on next page)

\footnotetext{
* Correspondence: tobias.deutsch@medizin.uni-leipzig.de

†'ohannes Quart and Tobias Deutsch contributed equally to this work.

'Department of General Practice, Medical Faculty, University of Leipzig,

Leipzig, Germany

Full list of author information is available at the end of the article
}

(c) The Author(s). 2018 Open Access This article is distributed under the terms of the Creative Commons Attribution 4.0 International License (http://creativecommons.org/licenses/by/4.0/), which permits unrestricted use, distribution, and reproduction in any medium, provided you give appropriate credit to the original author(s) and the source, provide a link to the Creative Commons license, and indicate if changes were made. The Creative Commons Public Domain Dedication waiver (http://creativecommons.org/publicdomain/zero/1.0/) applies to the data made available in this article, unless otherwise stated. 
(Continued from previous page)

Methoden: In dieser multizentrischen Querschnittsstudie wurden fünf Jahrgänge von Medizinstudierenden

(8. bis 10. Semester) aus drei Universitäten (Berlin, Halle, Leipzig) zu Ihrer Pendelbereitschaft befragt. Außerdem wurden maximal akzeptable Fahrzeiten und der Einfluss verschiedener Arbeitsbedingungen auf die Attraktivität des Pendelns erhoben.

Ergebnisse: Von 1203 Studierenden in den untersuchten Jahrgängen erhielten wir 1108 analysierbare Fragebögen (92.1\%). Für 55.9\% der Teilnehmer war es vorstellbar, zukünftig in ländliche oder kleinstädtische Regionen zu pendeln. Den stärksten positiven Einfluss auf die Attraktivität eines solchen Pendelmodells hatten eine Vergütung der Fahrzeiten, eine generell höhere Vergütung der Tätigkeit, die Arbeit in einer Gemeinschaftspraxis (2-3 Ärzte), die Entlastung durch qualifizierte „Versorgungsassistenten", die Bereitstellung eines Home-Office, eine gute Anbindung an öffentliche Verkehrsmittel und ein Fahrservice. Grundsätzlich betrug die maximal akzeptable Fahrzeit (eine Strecke) durchschnittlich 39.0 Minuten. Wäre die Fahrzeit bezahlt und Teil der regulären Arbeitszeit, würden die Teilnehmer durchschnittlich 51.2 Minuten je Strecke akzeptieren.

Schlussfolgerung: Die zukünftigen Ärzte stehen Pendelmodellen mehrheitlich offen gegenüber und könnten primär über Vergütung, Reduktion der Arbeitsbelastung und komfortable Beförderungsmöglichkeiten motiviert werden.

\section{Background}

There is a decrease in physicians in non-urban areas in many countries, including Germany [1-3]. Particularly the growing shortage of primary care physicians will increasingly threaten adequate medical care for an aging population in many regions [4]. The perspective of living in a non-urban area seems to be relatively unattractive for young physicians today [5]. The reasons are diverse and include perceptions of demanding working conditions, inadequate payment, limited opportunities for personal and professional development, less job opportunities for spouses as well as limited educational opportunities for children [2, 6]. Regardless of the medical profession, in Germany there is a general trend towards a concentration of the population in attractive urban regions. Interestingly, although particularly shaped by young adults starting out at their first job, this trend is not primarily linked to the local availability of jobs [7].

Several studies have been conducted to identify factors attracting or inhibiting young physicians establishing or taking over rural doctors' offices [8]. However, in some regions the population and thus the supply needs are continuously decreasing, querying the economic viability of local doctors' offices in the long run [9].

Particularly for those regions temporary solutions like commuting models might be a pragmatic option to fill gaps in healthcare availability. So far, little is known about future physicians' attitudes regarding commuting. This study aimed to examine medical students' willingness to commute in the future, maximum acceptable distances, and how different job-related factors might positively influence the willingness to commute.

\section{Methods}

\section{Sampling and design}

Between May 2015 and May 2016 we performed a cross-sectional questionnaire-based survey among 5 years of medical students (8th to 10th semester of altogether 10 semesters plus 2 semesters final clinical year) from three German universities (Charité Berlin, Halle, and Leipzig). In Leipzig, students completed the questionnaires at the beginning of a mandatory geriatric self-experience course (10th semester) and prior to the written exam following the lecture series in general practice (8th semester), respectively. In Halle, students completed the questionnaires at the end of a mandatory two-week general practice clerkship (9th semester). In Berlin, students answered the questionnaire at the beginning of a mandatory general practice seminar (10th semester).

\section{Questionnaire}

We used a self-developed questionnaire created by a multidisciplinary team (general practitioner, general practice resident, psychologist, and economist). To ensure comprehensibility, usability and face validity, the questionnaire was pre-tested with two medical students in advanced study years (target group). The pre-testing procedure was oriented towards the qualitative method of concurrent think aloud (CTA) and led to minor adjustments with regard to content and form.

Survey participants were questioned about relevant socio-demographic information, current career preferences, their willingness to commute to a non-urban area while living in an urban environment (as a hypothetical scenario), and the maximum acceptable commute time (one-way from home to workplace/ door to door). Furthermore, they were asked to assess how several work-related factors would positively influence their readiness to commute.

\section{Statistical analysis}

Data were analyzed using IBM SPSS Statistics 24 for Windows. As N's may vary due to missing values, frequencies are presented as $\%_{\text {valid }}\left(\mathrm{n}_{\text {absolute }} / \mathrm{n}_{\text {valid }}\right)$. Continuous 
variables are presented as mean \pm standard deviation (SD). Chi-square test was used for group comparisons with regard to frequencies. Continuous variables were compared using the Mann-Whitney $U$ test in the case of two groups and the Kruskal-Wallis test in the case of more than two groups. Statistical significance was assumed for $p<0.05$.

\section{Cartographic presentation (isochrones map)}

To illustrate the practical consequences of our results regarding the maximum accepted commute times within different scenarios we created a geographical map with isochrones lines. As a map of Germany would have been too complex, we decided to show the areas of Saxony potentially covered by commuting. The underlying commuting times were nevertheless derived from the whole sample (including Halle, Leipzig, and Berlin). As in Germany medical study places are awarded centrally, primarily based on school leaving examinations, students' places of origin, study places, and later workplaces are often not the same. Considering this, although focusing on the example of Saxony, the use of all data seemed to be most realistic. We used ISO4APP API [10], a software tool based on "openstreetmap" [11], which is made available for free under the Open Database License [12]. The isochrones lines were created for the scenario of driving by car at average daily traffic from the city-center of one of the three big cities in Saxony with more than 100,000 inhabitants (Dresden, Chemnitz, and Leipzig).

\section{Results}

Out of altogether 1203 students 1114 returned a questionnaire. After the exclusion of six only fragmentarily filled out forms the analyzable sample size was 1108, corresponding to a response rate of $92.1 \%$. The participants' age was on average $25.3 \pm 3.2$ years and $64.4 \%$ (714/1108) were women. Detailed sample characteristics are shown in Table 1. For $11.8 \%$ (126/1069) of the students, general practice was the currently preferred career option. With regard to their future place of residence $71.1 \%(779 / 1096)$ of the students stated that they could imagine to live in a big city, 64.6\% (708/1096) could imagine to live in a small town and $42.7 \%(468 / 1096)$ in a rural area (multiple answers were possible). For $24.5 \%$ $(269 / 1096)$ of the participants living in a big city was the only option.

Regarding whether they can imagine commuting to a rural/small-town area for work while living in a big city (as a hypothetical scenario), 10.4\% (115/1106) of the participants answered "definitely yes", 45.5\% (503/1106) "rather yes", 35.7\% (395/1106) "rather no", and 8.4\% (93/ 1106) "definitely no". Among those who considered a big city as their future place of residence 60.7\% (472/777) could imagine commuting to a rural/small-town area ("definitely yes" or "rather yes"). Among those who stated that living in a big city is the only option $44.2 \%$ (118/ 267 ) could imagine commuting ("definitely yes" or "rather yes"). Based on bivariate comparisons we found no

Table 1 Sample characteristics

\begin{tabular}{|c|c|c|}
\hline Variable & valid $(\mathrm{N})^{\mathrm{a}}$ & $N(\%)^{b}$ \\
\hline Sub-Sample (university, year, course, semester) & 1108 & \\
\hline Leipzig, 2016, geriatric self-experience course, 10th semester & & $259(23.4)$ \\
\hline Leipzig, 2015, geriatric self-experience course, 10th semester & & $259(23.4)$ \\
\hline Leipzig, 2016, general practice exam, 8th semester & & $274(24.7)$ \\
\hline Berlin, 2015, general practice seminar, 10th semester & & $159(14.4)$ \\
\hline Halle, 2015, two-week general practice clerkship, 9th semester & & $157(14.2)$ \\
\hline Age $[$ mean $\pm S D]$ & 1103 & $25.3 \pm 2.3$ \\
\hline Female gender & 1108 & $714(64.4)$ \\
\hline Living in a stable relationship & 1089 & $680(62.4)$ \\
\hline Having children & 1094 & $98(9.0)$ \\
\hline At least one parent with university degree & 1100 & $837(76.1)$ \\
\hline Being a physician's child & 1106 & $290(26.2)$ \\
\hline Family or friends in general practice & 1104 & $341(30.9)$ \\
\hline Pre-existing concluded education in a medical occupation & 1103 & $244(22.1)$ \\
\hline Mainly grew up in ... & 1098 & \\
\hline ... big city & & $422(38.4)$ \\
\hline ... small town & & 369 (33.6) \\
\hline ... rural area & & $307(28.0)$ \\
\hline
\end{tabular}

${ }^{a} \mathrm{~N}$ 's vary due to missing values

${ }^{b}$ Unless otherwise indicated 
significant associations between the willingness to commute ("definitely/rather yes" vs. "rather/definitely no") and the variables gender, age, university, stable relationship, having children, regional background, pre-existing concluded education in a medical occupation, and current GP career preference (data not shown).

Basically, the maximum acceptable commute time (one-way) for the surveyed students was on average $39.0 \pm 13.3 \mathrm{~min}(N=1098)$. Regarding the scenario of living in an urban but working in a rural/small-town environment, the maximum acceptable commute time varied depending on different modes of transport and payment (Table 2). The participants accepted the longest commute time if it would be a salaried and integral part of the working time $(51.2 \pm 22.6 \mathrm{~min})$. Based on these time specifications (basic and longest acceptable time), an exemplary map of Saxony showing areas potentially covered by commuting is presented in Fig. 1.

We found no significant associations between the maximum acceptable commute time (one-way) and the variables gender, age, stable relationship, having children, pre-existing concluded education in a medical occupation, and current GP career preference (data not shown). However, there were significant differences depending on university (Halle: $35.6 \pm 12.1 \mathrm{~min}$, Leipzig: $38.1 \pm 12.6 \mathrm{~min}$, Berlin: $46.6 \pm 15.5 \mathrm{~min} ; p<0.001)$ and regional background (mainly grew up in big city: $40.9 \pm 14.0 \mathrm{~min}$, small-town: $38.8 \pm 13.7 \mathrm{~min}$, rural area: $36.6 \pm 11.5 \mathrm{~min}$; $p<0.001)$.

The participants were asked to what extent various job-related factors would increase the attractiveness of commuting to a rural/small-town area (scale from $0=$ ' $n o$ increase' to 4='very strong increase'). The respective results are provided in Fig. 2 as relative frequencies (100\% bar charts) and in Table 3 as means \pm SD (overall and depending on gender and current GP career preference).

\section{Discussion}

This study shows that more than half of German medical students in an advanced stage of undergraduate medical education can imagine a scenario of commuting to a future workplace in a non-urban area while living in a big city. The most crucial factors that might increase the attractiveness of commuting were associated with higher remuneration, reduction of the physicians' burden (e.g. via joint practices or a qualified supply assistance), and comfortable modes of transport.

\section{Main findings in relation to other studies}

We found no other studies directly addressing the factors influencing willingness of future physicians to commute to a workplace in a non-urban area while living in a big city. So far, most studies have focused mainly on how to convince physicians to settle down in rural areas $[2,6,13-16]$. Other studies have examined general health aspects of commuting or the commuting behavior of the whole population without consideration of specific professional subgroups [17-19]. Consequently, our results are only partially comparable to the existing literature.

More than half of our study participants were open-minded about commuting to a rural/small town area ("definitely yes" or "rather yes"). Thus, a substantial percentage of future physicians might be convinced, if not to live, then at least to work in non-urban areas if the right measures are taken. For general comparison, it can be stated that currently $60 \%$ of the German population commute (home and workplace in different municipalities) [18]. Despite several studies implying relations between the willingness to commute and sociodemographic variables like gender and age [19-21], we found no such associations in our data. However, it must be considered that we examined a homogenous age group of students in their mid-twenties, and respective associations might develop later on, when life circumstances change after graduation [19].

In our study the most important factors increasing the attractiveness of commuting were associated with remuneration, disburdening the physician, and comfortable modes of transportation. Previous studies investigating the willingness of physicians to establish a practice or to live and work in a rural area have also underlined the influence of money $[6,13,22]$, flexible working times

Table 2 Maximum acceptable commute time to work (one-way) depending on different conditions

\begin{tabular}{|c|c|c|c|c|c|}
\hline \multirow[t]{2}{*}{ Maximum acceptable commute time (one-way) if ... } & \multirow{2}{*}{$\begin{array}{l}\text { valid } \\
\mathrm{N}\end{array}$} & \multirow{2}{*}{$\begin{array}{l}\text { Mean } \pm S D \\
\text { in minutes }\end{array}$} & \multicolumn{3}{|c|}{ Quartiles (minutes) } \\
\hline & & & $25 \%$ & $50 \%$ & $75 \%$ \\
\hline$\ldots$ I go by car & 1084 & $36.1 \pm 12.9$ & 30.0 & 30.0 & 45.0 \\
\hline$\ldots$ I go by public transport & 1083 & $40.3 \pm 15.2$ & 30.0 & 40.0 & 45.0 \\
\hline ... I can take part in a car pool & 1064 & $35.5 \pm 13.9$ & 30.0 & 30.0 & 45.0 \\
\hline$\ldots$ I get picked up by a driver service & 1065 & $39.1 \pm 15.6$ & 30.0 & 30.0 & 45.0 \\
\hline ... time getting to work is paid as working time, additional to it & 1075 & $47.0 \pm 18.3$ & 30.0 & 45.0 & 60.0 \\
\hline ... time getting to work is paid as working time, included into it & 1069 & $51.2 \pm 22.6$ & 30.0 & 50.0 & 60.0 \\
\hline ... time getting to work is utilizable for organizational tasks & 1066 & $43.9 \pm 19.0$ & 30.0 & 45.0 & 60.0 \\
\hline
\end{tabular}




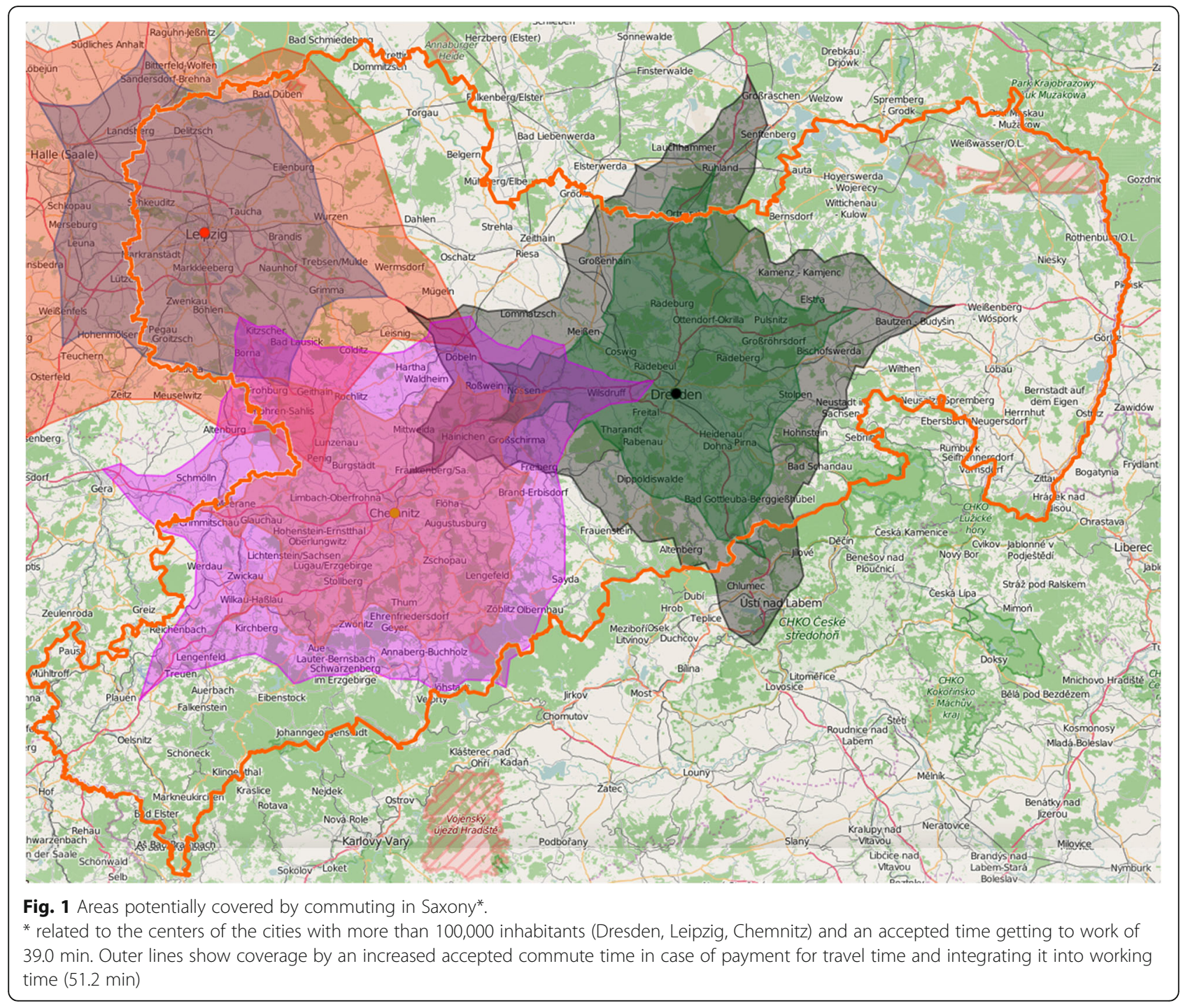

including part-time work [22-24], the possibility to work in a group practice $[6,13,25]$, working as an employee $[6,16,24]$, and a reduced workload by extended medical staff competencies and delegation ("supply assistant") [3, 24].

Our results indicate slight but significant gender differences regarding the job-related conditions increasing the attractiveness of commuting. For women, a reduction of the workload through alternative working arrangements (part-time, job-sharing, joint practice, working as employee, home-office) as well as possibilities to avoid daily car driving (through pick up service or car pool) seem to be more attractive than for men. This may be seen in line with a previous study on young physicians' decision to establish a practice that has also shown job cooperation possibilities, reduced workload and good reconciliation of work and family to be more important to female physicians [26].

Furthermore, we found that students interested in a GP career were significantly more attracted by part-time working models, single or small joint practices and a disburdening by "supply assistants" than their counterparts favoring other specialties. A current study examining the preferences of GP trainees regarding practice size and weekly working hours also found them to be attracted to work in small shared practices. However, this study found no direct preference to work less hours per week as long as salary is appropriate for the workload [27].

Among the participants of our study the acceptable commute time was on average $39 \mathrm{~min}$. A survey from 2010 among German general practice residents found that $72 \%$ would accept up to $30 \mathrm{~min}$, but only $13 \%$ up to $60 \mathrm{~min}$ one way [6]. For the whole German working population it has been shown that about $47 \%$ have a way to work of 10 to $30 \mathrm{~min}$ and about $22 \%$ a way of 30 to $60 \mathrm{~min}$ [28]. Our results indicate regional differences in the acceptable commute time depending on the university attended (Halle<Leipzig<Berlin). Considering the 


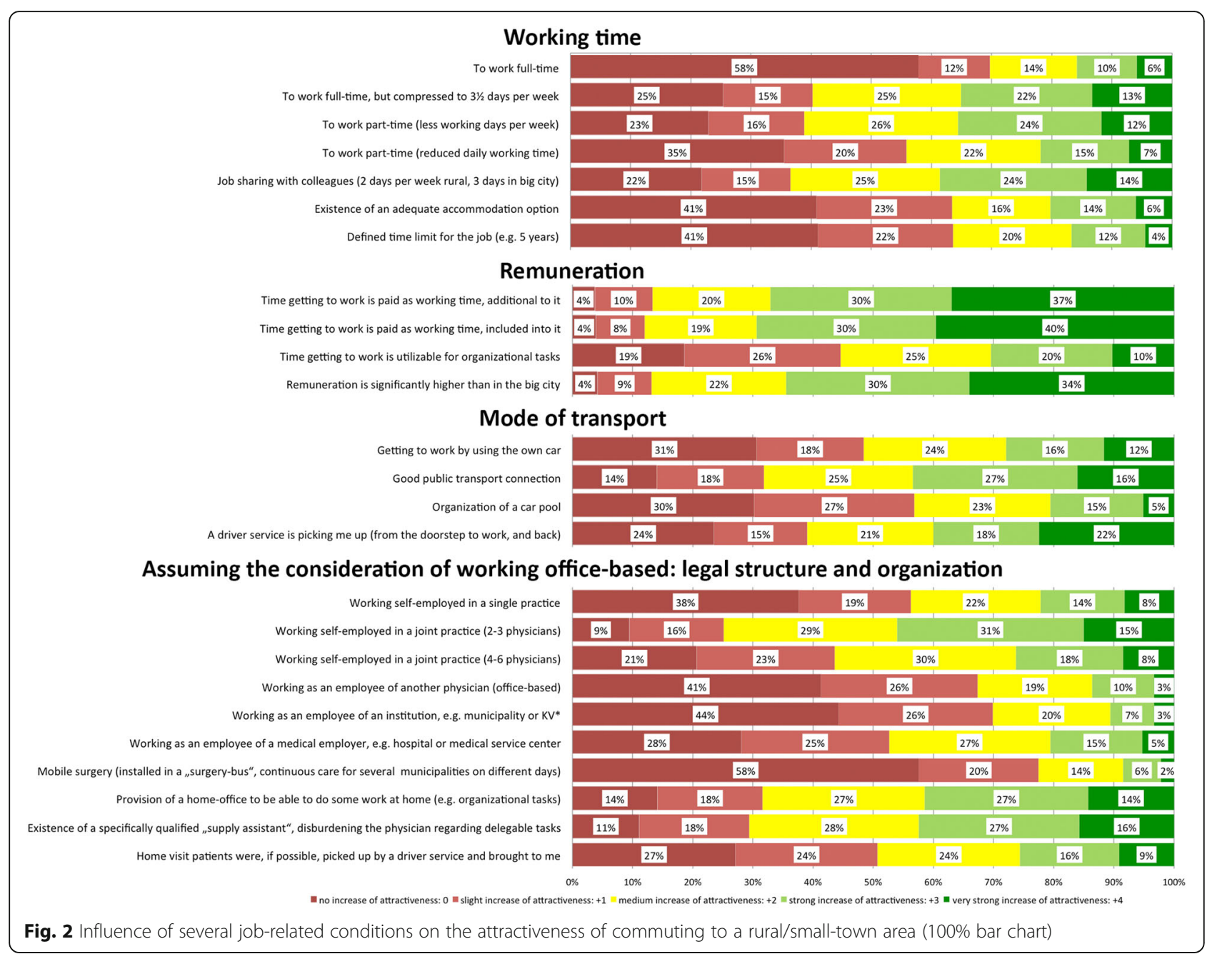

significantly different size of these cities it may be assumed that students in Berlin are simply used to longer commute times. This is supported by data of the German federal statistical office indicating longer commute times among people living in conurbations [28].

Since a nationwide map would have been hard to read, we chose Saxony as an example to illustrate areas potentially covered by the accepted commute times found in our study. Furthermore, a current report of the Saxon federal government provides sufficient and detailed comparative data concerning regional medical care supply problems [9]. Altogether, our map indicates that not every Saxon region would be able to cover healthcare supply needs via commuting models. Interestingly, the areas not covered are currently those with the biggest difficulties [9].

\section{Implications for practice and further research}

To attract young physicians to commute to non-urban areas, the respective working conditions should be modified to ensure good remuneration and minimalized loss of leisure time. The focus should be particularly on tailored working models (flexible working times, part-time work, joint practices, job sharing, home office) as well as reducing the physicians' workload (e.g. through support by specifically qualified medical staff with extended competencies). Furthermore, our results emphasize the importance of paying adequately for commute time and providing comfortable transportation options. Further research is needed to verify the possibly higher acceptance of commuting in comparison to conventional "live-and-work" models and to identify more factors that might increase willingness to commute. Additionally, it would be interesting to replicate our survey among residents and young medical specialists.

\section{Strengths and limitations}

This study addresses a rarely studied, innovative topic of potential practical relevance regarding the future medical supply in non-urban areas. Medical undergraduates in advanced study years constitute a relevant target group - the future physicians. The sufficient sample size, the very good response rate and the inclusion of three 
Table 3 Influence of several job-related conditions on the attractiveness of commuting to a rural/small-town area - differences due to gender and general practice career preference

\begin{tabular}{|c|c|c|c|c|c|c|c|}
\hline \multirow[t]{3}{*}{ Potential influence factor } & \multicolumn{7}{|c|}{$\begin{array}{l}\text { Students' assessment of the increase of the attractiveness of commuting } \\
(0=n o \text { increase, }+1=\text { slight increase, }+2=\text { medium increase, }+3=\text { strong } \\
\text { increase, }+4=\text { very strong increase) }\end{array}$} \\
\hline & \multirow{2}{*}{ All } & \multirow{2}{*}{$\begin{array}{l}\text { Male } \\
\text { Mean } \pm \text { SD }\end{array}$} & \multirow{2}{*}{$\begin{array}{l}\text { Female } \\
\text { Mean } \pm \text { SD }\end{array}$} & \multirow[t]{2}{*}{$p^{*}$} & \multirow{2}{*}{$\begin{array}{l}\text { GP career } \\
\text { preferred } \\
\text { Mean } \pm \text { SD }\end{array}$} & \multirow{2}{*}{$\begin{array}{l}\text { Others } \\
\text { Mean } \pm \text { SD }\end{array}$} & \multirow[t]{2}{*}{$p^{*}$} \\
\hline & & & & & & & \\
\hline \multicolumn{8}{|l|}{ Working time } \\
\hline To work full-time & $0.9 \pm 1.3$ & $1.1 \pm 1.4$ & $0.8 \pm 1.2$ & 0.003 & $1.0 \pm 1.3$ & $1.0 \pm 1.3$ & 0.882 \\
\hline $\begin{array}{l}\text { To work full-time, but compressed to } 3 \frac{1}{2} \text { days } \\
\text { per week }\end{array}$ & $1.8 \pm 1.4$ & $1.8 \pm 1.4$ & $1.8 \pm 1.4$ & 0.984 & $2.1 \pm 1.4$ & $1.8 \pm 1.4$ & 0.044 \\
\hline To work part-time (less working days per week) & $1.9 \pm 1.3$ & $1.6 \pm 1.3$ & $2.0 \pm 1.3$ & $<0.001$ & $2.2 \pm 1.3$ & $1.8 \pm 1.3$ & 0.005 \\
\hline To work part-time (reduced daily working time) & $1.4 \pm 1.3$ & $1.1 \pm 1.2$ & $1.5 \pm 1.3$ & $<0.001$ & $1.9 \pm 1.4$ & $1.3 \pm 1.3$ & $<0.001$ \\
\hline $\begin{array}{l}\text { Job sharing with colleagues ( } 2 \text { days per week rural, } \\
3 \text { days in big city) }\end{array}$ & $1.9 \pm 1.4$ & $1.8 \pm 1.3$ & $2.0 \pm 1.3$ & 0.002 & $2.0 \pm 1.5$ & $2.0 \pm 1.3$ & 0.954 \\
\hline Existence of an adequate accommodation option & $1.2 \pm 1.3$ & $1.4 \pm 1.3$ & $1.2 \pm 1.3$ & 0.012 & $1.2 \pm 1.3$ & $1.2 \pm 1.3$ & 0.723 \\
\hline Defined time limit for the job (e.g. 5 years) & $1.2 \pm 1.2$ & $1.2 \pm 1.2$ & $1.2 \pm 1.2$ & 0.915 & $1.1 \pm 1.2$ & $1.2 \pm 1.2$ & 0.243 \\
\hline \multicolumn{8}{|l|}{ Remuneration } \\
\hline $\begin{array}{l}\text { Time getting to work is paid as working time, } \\
\text { additional to it }\end{array}$ & $2.9 \pm 1.1$ & $2.9 \pm 1.1$ & $2.9 \pm 1.1$ & 0.876 & $2.9 \pm 1.2$ & $2.9 \pm 1.1$ & 0.683 \\
\hline $\begin{array}{l}\text { Time getting to work is paid as working time, } \\
\text { included into it }\end{array}$ & $2.9 \pm 1.1$ & $2.9 \pm 1.2$ & $3.0 \pm 1.1$ & 0.266 & $3.0 \pm 1.1$ & $2.9 \pm 1.1$ & 0.334 \\
\hline Time getting to work is utilizable for organizational tasks & $1.8 \pm 1.3$ & $1.9 \pm 1.2$ & $1.7 \pm 1.3$ & 0.048 & $1.9 \pm 1.3$ & $1.8 \pm 1.2$ & 0.174 \\
\hline Remuneration is significantly higher than in the big city & $2.8 \pm 1.1$ & $2.8 \pm 1.2$ & $2.8 \pm 1.1$ & 0.647 & $2.9 \pm 1.1$ & $2.8 \pm 1.1$ & 0.436 \\
\hline \multicolumn{8}{|l|}{ Mode of transport } \\
\hline Getting to work by using own car & $1.6 \pm 1.4$ & $1.7 \pm 1.4$ & $1.6 \pm 1.4$ & 0.352 & $1.6 \pm 1.4$ & $1.6 \pm 1.4$ & 0.903 \\
\hline Good public transport connection & $2.1 \pm 1.3$ & $2.1 \pm 1.3$ & $2.2 \pm 1.3$ & 0.223 & $2.2 \pm 1.3$ & $2.1 \pm 1.3$ & 0.539 \\
\hline Organization of a car pool & $1.4 \pm 1.2$ & $1.3 \pm 1.2$ & $1.5 \pm 1.2$ & 0.017 & $1.4 \pm 1.2$ & $1.4 \pm 1.2$ & 0.611 \\
\hline $\begin{array}{l}\text { A driver service is picking me up (from the doorstep } \\
\text { to work, and back) }\end{array}$ & $2.0 \pm 1.5$ & $1.9 \pm 1.5$ & $2.1 \pm 1.5$ & 0.020 & $1.8 \pm 1.6$ & $2.0 \pm 1.5$ & 0.149 \\
\hline \multicolumn{8}{|c|}{ Assuming the consideration of working office-based: legal structure and organization } \\
\hline Working self-employed in a single practice & $1.4 \pm 1.3$ & $1.5 \pm 1.4$ & $1.3 \pm 1.3$ & 0.024 & $1.8 \pm 1.4$ & $1.3 \pm 1.3$ & $<0.001$ \\
\hline $\begin{array}{l}\text { Working self-employed in a joint practice } \\
\text { ( } 2-3 \text { physicians) }\end{array}$ & $2.3 \pm 1.2$ & $2.0 \pm 1.2$ & $2.4 \pm 1.1$ & $<0.001$ & $2.7 \pm 1.2$ & $2.2 \pm 1.2$ & $<0.001$ \\
\hline $\begin{array}{l}\text { Working self-employed in a joint practice } \\
\text { (4-6 physicians) }\end{array}$ & $1.7 \pm 1.2$ & $1.6 \pm 1.2$ & $1.8 \pm 1.2$ & 0.014 & $1.8 \pm 1.3$ & $1.7 \pm 1.2$ & 0.337 \\
\hline $\begin{array}{l}\text { Working as an employee of another physician } \\
\text { (office-based) }\end{array}$ & $1.1 \pm 1.1$ & $0.8 \pm 1.0$ & $1.2 \pm 1.2$ & $<0.001$ & $1.4 \pm 1.3$ & $1.0 \pm 1.1$ & 0.002 \\
\hline $\begin{array}{l}\text { Working as an employee of an institution, e.g. } \\
\text { municipality or } \mathrm{KV}^{\mathrm{a}}\end{array}$ & $1.0 \pm 1.1$ & $0.9 \pm 1.1$ & $1.1 \pm 1.1$ & 0.003 & $1.4 \pm 1.3$ & $0.9 \pm 1.1$ & $<0.001$ \\
\hline $\begin{array}{l}\text { Working as an employee of a medical employer, } \\
\text { e.g. hospital or medical service center }\end{array}$ & $1.5 \pm 1.2$ & $1.2 \pm 1.1$ & $1.6 \pm 1.2$ & $<0.001$ & $1.6 \pm 1.3$ & $1.5 \pm 1.2$ & 0.432 \\
\hline $\begin{array}{l}\text { Mobile surgery (installed in a 'surgery-bus', continuous } \\
\text { care for several municipalities on different days) }\end{array}$ & $0.8 \pm 1.1$ & $0.7 \pm 1.0$ & $0.8 \pm 1.1$ & 0.749 & $1.2 \pm 1.3$ & $0.7 \pm 1.0$ & $<0.001$ \\
\hline $\begin{array}{l}\text { Provision of a home-office to be able to do some work } \\
\text { at home (e.g. organizational tasks) }\end{array}$ & $2.1 \pm 1.3$ & $1.9 \pm 1.2$ & $2.2 \pm 1.3$ & $<0.001$ & $2.4 \pm 1.2$ & $2.1 \pm 1.3$ & 0.022 \\
\hline $\begin{array}{l}\text { Existence of a specifically qualified "supply assistant", } \\
\text { disburdening the physician regarding delegable tasks }\end{array}$ & $2.2 \pm 1.2$ & $2.1 \pm 1.2$ & $2.2 \pm 1.2$ & 0.010 & $2.6 \pm 1.2$ & $2.1 \pm 1.2$ & $<0.001$ \\
\hline $\begin{array}{l}\text { Home visit patients were, if possible, picked up by a } \\
\text { driver service and brought to me }\end{array}$ & $1.6 \pm 1.3$ & $1.6 \pm 1.3$ & $1.5 \pm 1.3$ & 0.245 & $1.6 \pm 1.3$ & $1.6 \pm 1.3$ & 0.926 \\
\hline
\end{tabular}


different universities support the representativeness of the results. As a validated instrument fitting to our research questions and the target group was not available, we used a self-developed questionnaire. This might be discussed as a possible limitation. However, the thorough development by an experienced multidisciplinary team and the pre-testing of the questionnaire ensure at least face validity. Another limitation might result from the fact that we asked medical students about a topic that becomes really relevant only after graduation. It can't be excluded that some of the participants' perceptions might alter when life circumstances are changing. Furthermore, it should be considered that the list of conditions potentially influencing the attractiveness of commuting examined in our study is probably not exhaustive (e.g. we did not ask for participation in medical emergency services). The focus of this study was on the students' general open-mindedness regarding models of commuting to a non-urban workplace while living in a big city. We didn't discuss extensively how many students in our sample might decide to have their future place of residence in non-urban regions. As these scenarios cannot be considered as completely independent, this should be kept in mind when interpreting our results. Finally, it should be mentioned that, due to technical restrictions, our cartographic presentation is based on very limited presuppositions (using a car, starting at the city center, average traffic). Consequently, geographical conclusions should be drawn with respective care.

\section{Conclusion}

Many future physicians are open-minded regarding models of commuting to non-urban areas. There are several possibilities to moderately increase the attractiveness of such models through customized working conditions, particularly with regard to remuneration, working time, a reduction of the physicians' burden (e.g. joint practice, specifically qualified supply assistance), as well as the provision of comfortable modes of transport. Regions further from big cities (approximately more than $1 \mathrm{~h}$ ) may not be able to close gaps in medical care supply through commuting models.

\section{Acknowledgements}

The authors want to thank Prof. Dr. Andreas Klement (Halle), Prof. Dr. Christoph Heintze (Berlin), the "Stiftung Perspektive Hausarzt" (Foundation Perspective General Practitioner) as well as the "Sächsischer Hausärzteverband" (Saxon Association of Family Physicians) for supporting this study.

\section{Funding}

This study was primarily financed with own funds. A small financial support was provided by the "Stiftung Perspektive Hausarzt" (Foundation Perspective General Practitioner)

\section{Availability of data and materials}

The datasets used for the current study are available from the corresponding author on reasonable request.

\section{Authors' contributions}

JQ contributed to the conception and design of the study, the collection, analysis, interpretation, and visualization of the data, and was the main contributor regarding the initial draft of the manuscript. TD contributed to the conception and methodology of the study, and supported data analysis and interpretation, as well as writing the manuscript. SC contributed to data interpretation, and critically commented and revised the manuscript. SD contributed to data collection, and critically commented and revised the manuscript. TF initiated and supervised the study, contributed to conception and data interpretation, and revised the manuscript. All authors read and approved the final version of the manuscript.

\section{Ethics approval and consent to participate}

According to the regulations of the ethics committee of the Leipzig Medical Faculty and the Model Professional Code for Physicians an explicit ethical approval was deemed unnecessary for this study. After being informed about the study, all participants completed this anonymous survey on a voluntary basis (informed consent)

\section{Competing interests}

The authors declare that they have no competing interests.

\section{Publisher's Note}

Springer Nature remains neutral with regard to jurisdictional claims in published maps and institutional affiliations.

\section{Author details}

'Department of General Practice, Medical Faculty, University of Leipzig, Leipzig, Germany. ${ }^{2}$ Institute of General Practice and Family Medicine, Martin-Luther-University Halle-Wittenberg, Halle/Saale, Germany. Institute of General Practice, Charité-Universitätsmedizin Berlin, Berlin, Germany.

Received: 27 November 2017 Accepted: 16 May 2018 Published online: 29 May 2018

\section{References}

1. Dussault G, Franceschini MC. Not enough there, too many here: understanding geographical imbalances in the distribution of the health workforce. Hum Resour Health. 4:12. https://doi.org/10.1186/1478-4491-4-12.

2. Grobler L, Marais BJ, Mabunda S. Interventions for increasing the proportion of health professionals practising in rural and other underserved areas. Cochrane Database Syst Rev. 2015:CD005314. https://doi.org/10.1002/ 14651858.CD005314.pub3.

3. Ono T, Schoenstein M, Buchan J. Geographic Imbalances in Doctor Supply and Policy Responses. OECD Health Working Papers, No. 69. Paris: OECD Publishing; 2014. https://doi.org/10.1787/5jz5sa5ls1wl-en

4. Colwill JM, Cultice JM, Kruse RL. Will generalist physician supply meet demands of an increasing and aging population? Health Aff (Millwood). 2008;27:w232-41. https://doi.org/10.1377/hlthaff.27.3.w232.

5. Gibis B, Heinz A, Jacob R, Muller C-H. The career expectations of medical students: findings of a nationwide survey in Germany. Deutsches Ärzteblatt international. 2012;109:327-32. https://doi.org/10.3238/arztebl.2012.0327.

6. Steinhäuser J, Annan N, Roos M, Szecsenyi J, Joos S. Lösungsansatze gegen den Allgemeinarztmangel auf dem Land-Ergebnisse einer Online-Befragung unter Ärzten in Weiterbildung. Dtsch Med Wochenschr. 2011;136:1715-9. https://doi.org/10.1055/s-0031-1272576.

7. Empirica ag. Schwarmverhalten in Sachsen - eine Untersuchung zu Umfang, Ursache, Nachhaltigkeit und Folgen der neuen Wanderungsmuster. Berlin: Sächsische Aufbaubank, Verband der Wohnungs- und Immobilienwirtschaft in Sachsen, Verband sächsischer Wohnungsgenossenschaften; 2016.

8. Langer A, Ewert T, Hollederer A, Geuter G. Literaturüberblick über niederlassungsfördernde und -hemmende Faktoren bei Ärzten in Deutschland und daraus abgeleitete Handlungsoptionen für Kommunen. Gesundh ökon Qual manag. 2015;20:11-8. https://doi.org/10.1055/s-0033-1356303.

9. Versorgungs- und Arztbedarf in Sachsen: Kurzbericht Gutachten zur Entwicklung des ambulanten Versorgungs- und Arztbedarfs in Sachsen. Dresden: Sächsisches Staatsministerium für Soziales und Verbraucherschutz: 2016.

10. ISO4APP API. https://www.iso4app.net. Accessed 26 Feb 2017.

11. Geofabrik Openstreetmap. http://download.geofabrik.de. Accessed 26 Feb 2017. 
12. Open Data Commons. Open Database License (ODbL) v1.0. http:// opendatacommons.org/licenses/odbl/1.0/. Accessed 26 Feb 2017.

13. Holte JH, Kjaer T, Abelsen B, Olsen JA. The impact of pecuniary and nonpecuniary incentives for attracting young doctors to rural general practice. Soc Sci Med. 2015;128:1-9. https://doi.org/10.1016/j.socscimed.2014.12.022.

14. Roick C, Heider D, Gunther OH, Kurstein B, Riedel-Heller SG, Konig HH. Was ist künftigen Hausärzten bei der Niederlassungsentscheidung wichtig? Ergebnisse einer postalischen Befragung junger Ärzte in Deutschland. Gesundheitswesen (Bundesverband der Ärzte des Öffentlichen Gesundheitsdienstes (Germany)). 2012;74:12-20. https://doi.org/10.1055/s-0030-1268448.

15. Schmacke N. Ärztemangel: Viele Fragen werden noch nicht diskutiert. Gesundheit und Gesellschaft : G + G. 2006;6:18-25.

16. Laurence CO, Williamson V, Sumner KE, Fleming J. "Latte rural": the tangible and intangible factors important in the choice of a rural practice by recent GP graduates. Rural Remote Health. 2010:10:1316.

17. Lindstrom M. Means of transportation to work and overweight and obesity: a population-based study in southern Sweden. Prev Med. 2008;46:22-8. https://doi.org/10.1016/j.ypmed.2007.07.012.

18. Bundesinstituts für Bau-, Stadt- und Raumforschung (BBSR). Immer mehr Menschen pendeln zur Arbeit. 2017. http://www.bbsr.bund.de/BBSR/DE/ Home/Topthemen/2017-pendeln.html. Accessed 5 Apr 2017.

19. Pfaff S. Pendeln oder umziehen? Ursachen und Folgen berufsbedingter räumlicher Mobilität in Deutschland. Karlsruhe: KIT-Bibliothek; 2013.

20. Eckey H-F, Kosfeld R, Türck M. Pendelbereitschaft von Arbeitnehmern in Deutschland: willingness to commute of employees in Germany. Raumforschung und Raumordnung: RuR. 2007:65:5-14.

21. Ruppenthal $S$, Lück D. Jeder fünfte Erwerbstätige ist aus beruflichen Gründen mobil : berufsbedingte räumliche Mobilität im Vergleich. Informationsdienst Soziale Indikatoren. 2009:1-5.

22. Scott A, Witt J, Humphreys J, Joyce C, Kalb G, Jeon S-H, McGrail M. Getting doctors into the bush: general practitioners' preferences for rural location. Soc Sci Med. 2013;96:33-44. https://doi.org/10.1016/j.socscimed.2013.07.002.

23. Kearns R, Myers J, Adair V, Coster H, Coster G. What makes 'place' attractive to overseas-trained doctors in rural New Zealand? Health Soc Care Community. 2006;14:532-40. https://doi.org/10.1111/j.1365-2524.2006.00641.X.

24. Sachverständigenrat zur Begutachtung der Entwicklung im Gesundheitswesen. Bedarfsgerechte Versorgung: Perspektiven für ländliche Regionen und ausgewählte Leistungsbereiche. Köln: Bundesanzeiger Verlag; 2014.

25. Höppner K. Maarse JAM. Planung und Sicherung der hausärztlichen Versorgung in den Niederlanden. Gesundheit und Gesellschaft : G + G. 2003;3:21-31.

26. Stengler K, Heider D, Roick C, Gunther OH, Riedel-Heller S, Konig H-H. Weiterbildungsziel und Niederlassungsentscheidung bei zukunftigen Facharztinnen und Facharzten in Deutschland. Eine genderspezifische Analyse Bundesgesundheitsblatt Gesundheitsforschung Gesundheitsschutz. 2012:55:121-8. https://doi.org/10.1007/s00103-011-1397-8.

27. Pedersen LB, Gyrd-Hansen D. Preference for practice: a Danish study on young doctors' choice of general practice using a discrete choice experiment. Eur J Health Econ. 2014;15:611-21. https://doi.org/10.1007/s10198-013-0500-5.

28. Berufspendler: Infrastruktur wichtiger als Benzinpreis: STATmagazin: Arbeitsmarkt. Wiesbaden: Statistisches Bundesamt; 2014.

\section{Ready to submit your research? Choose BMC and benefit from:}

- fast, convenient online submission

- thorough peer review by experienced researchers in your field

- rapid publication on acceptance

- support for research data, including large and complex data types

- gold Open Access which fosters wider collaboration and increased citations

- maximum visibility for your research: over $100 \mathrm{M}$ website views per year

At BMC, research is always in progress.

Learn more biomedcentral.com/submissions 